\title{
Temporal variation of water discharges in the lower course of the Danube River across the area from Reni to Izmail under the influence of natural and anthropogenic factors
}

Yelyzaveta Romanova ${ }^{1}$,

Zhannetta Shakirzanova ${ }^{1}$,

Valeriya Ovcharuk ${ }^{1}$,

Olena Todorova ${ }^{1}$,

Iuliia Medvedieva²,

Andrii Ivanchenko ${ }^{3}$

${ }^{1}$ Odessa State Environmental University, Department of Land Hydrology, 15 Lvivska St., Odessa, Ukraine Email:lisaromanova@ukr.net, jannettodessa@gmail.com, valeriya.ovcharuk@gmail.com, elena.todorova1989@gmail.com

\author{
${ }^{2}$ National University \\ "Odessa Maritime Academy", \\ Maritime Technologies Department, \\ 8 Didrichson St., Odessa, Ukraine \\ Emailmedvedieva.onma@gmail.com \\ ${ }^{3}$ Odessa State Environmental University, \\ Department of Foreign Languages, \\ 15 Lvivska St., Odessa, Ukraine, \\ Email andrey.ivanchenko.86@gmail.com
}

The Danube River mouth is a main source for fresh water used for water supply and irrigation purposes in the arid southern part of Ukraine. In addition, the water of the mouth is used for filling the Danube Lakes. Climate change and numerous social and economic factors reduce the area and the water level of the Danube Lakes and increase their salinity. Under these circumstances the water exchange between the Danube River and the lakes is a very important process which allows maintenance of the water-salt balance of the latter. Such water exchange massively depends on the Danube River regime.

The paper presents research of temporal variation of typical water discharges in the lower course of the Danube River associated with assessment of natural and anthropogenic factors affecting river runoff fluctuations. Time series of annual average water discharge at the water gauging stations of such cities as Reni and Izmail were considered uniform for the selected periods. They cover the period of conventionally natural river runoff regime (1840-1920), the period of the least altered river runoff regime (1921-1960) and the most altered river runoff regime under a heavy anthropogenic influence (1961-1989). The analysis of the impact of climate changes on the river runoff allowed introduction of a new, modern period of the Danube River hydrological regime (1990-2015). It is established that the series of maximum and minimum water discharges are characterized by the lack of their uniformity from the beginning of the period of initial influence of hydraulic engineering structures on the hydrological regime (since 1961). The analysis of the aggregate multi-year series (1840-2015) of average annual, maximum and minimum water discharges of the Danube River across its length from Reni to Izmail showed the presence of positive trends. At the same time the period of climatic changes (after 1989) is characterized by a less intensive growth of maximum water discharges. The research resulted in establishing the periodicity and synchronism of water discharge fluctuations in the lower course of the Danube River from Reni to Izmail within the territory of Ukraine. In particular, the study showed for the first time 
that from the 2000s onwards the redistribution of river runoff between the Danube River branches led to unsynchronization of minimum river runoff in different parts of the Danube Delta. The research shows that comprehensive analysis of the Danube River hydrological regime under modern climatic conditions is required to ensure efficient engineering regulation of the Danube Lakes filling pattern. Such regulation, in its turn, will ensure that the water supply and irrigation purposes are achieved.

Keywords: Danube River, hydrological regime of river runoff, trend analysis, anthropogenic factors, climate change

\section{INTRODUCTION}

The hydrological regime of the Danube River and other world's largest rivers is influenced by both natural and anthropogenic factors, such as water resources use (water supply, land reclamation and fishing industry) and runoff regulation by hydraulic engineering structures [1-3].

Over the last two decades new hydropower plants have been designed and mega dams (more than $15 \mathrm{~m}$ high) have been built on the world's biggest rivers which allowed increase of hydropower capacity by 55\% from 2000 to 2015 [4]. In addition, large dams can be used for multiple purposes, such as irrigation, flood control and drinking water supply $[4,5]$. However, mega dams construction poses significant risks related to changes in the volume and timing of river runoff, downstream sediment, and also breach of hydro-ecological conditions of reservoirs [2].

Thus, the influence of economic activity on the basin of the Danube River and its tributaries began to be observed in 1921 [6], and the influence of hydraulic engineering structures began to be observed in 1961 [1]. The most significant anthropogenic influence on the runoff of Lower Danube was caused by the following hydropower plants: Djerdap I (Iron Gate-I) in 1972 and Djerdap II (Iron Gate-II) in 1984. The latter was mainly aimed at compensating/balancing the water level in the lower basin of the first dam [1].

The authors [1] note that the construction of these water reservoirs did not significantly affect the runoff regime in the lower course of the Danube River because the main volume of water reserves forms in its upper and middle reaches. A detailed analysis of the influence of artificial dams of Iron Gate I and Iron Gate II is included in the authors' research [3].

The Danube River is one of the most efficient and environmentally friendly transport corridors which connects Western and Eastern Europe. According to the estimation [7], in terms of the European policy, only $10 \%$ of the waterway's transport capacity is being used. In particular, the restriction of shipping traffic is caused by fluctuations of the river's level, i.e. the presence of low levels during winter and summer periods causing an unsteady fairway [8]. It should be noted that the hydraulic engineering regulation of water level to ensure navigation depth across the lower Danube is performed only by means of dredging works (for example, in Bulgarian and Romanian port zones). However, such works are not always efficient [9]. 
The influence of hydraulic engineering structures also manifested itself in the multi-year redistribution of the Danube River runoff along the main branches of its delta (Kiliya and Tulcea) $[1,10,11]$. According to the Danube Commission, the water content of Kiliya mouth had been $62 \%$ of total water content of the Danube River and the water content of Tulcea mouth constituted $38 \%$ before the hydraulic engineering works were performed. The Tulcea mouth consists of Sulina mouth ( $8 \%$ of total water content) and St. George mouth (30\% of total water content). To ensure the passage of sea vessels from the sea to the Danube through the branches of the delta, in 1968-1982 respective hydraulic engineering works were carried out across the Sulina branch, and in 1981-1992 across St. George branch (within the Romanian territory). Such hydraulic engineering works resulted in runoff redistribution between the delta's branches with increase of water content across the Romanian part - in the Tulcea branch (the Sulina branch to a greater extent) (up to 40.8-47.8\%), and its decrease across the Ukrainian part - in the Kiliya branch (up to 52.0-55.1\%). Currently, the Danube River runoff is more or less equally distributed between the Tulcea and Kiliya branches [10, 11].

Some of the authors $[2,3]$ note that highspeed and large-scale anthropogenic transformations (big multi-purpose dams, construction of hydropower plants, physical and chemical pollution, appearance of non-typical biotic species, sedimentation) over a few years or even decades may potentially lead to irrecoverable transformations, and on some large rivers - to possible collapse of their ecosystems.

Over the last decades, the problem of river runoff assessment under the conditions of water management changes was supplemented by the problem of estimating the impact of global and regional climate changes on the rivers' water resources [2,12-14], including the ones in Ukraine [14-16].

Over the last thirty years of the retrospective period we could observe gradual increase in average annual air temperature which usually leads to spatial and temporal changes of precipitation and evapotranspiration regimes $[2,14,16]$. Climate change is a dominant factor affecting changes of water resources in the Danube River
Basin [17]. It leads to the changes in the volumes of runoff and sediments, changes of thermal and ice regimes, redistribution of water resources, etc. $[2,14]$. Climate change affects European rivers by changing the timing of floods. Changes in floods timing are associated with such factors as difference over time of the snow melting process, alteration of maximum soil moisture and changes of large atmospheric processes [2, 18].

The results of climate change modelling show that $[12,19]$ further increase in air temperature will increase the probability of extreme precipitation in most of the world. The growth in evaporation rate may increase the frequency of extreme floods and decrease the water resources of large territories $[2,14]$.

Over the last years there were some scientific works which analysed changes of hydrological regimes of river runoff associated with air temperature change, spatial and temporal changes of precipitation and evapotranspiration regimes in the Danube River countries, such as Germany [20], Switzerland [21], Austria [22], Slovenia [23], Croatia [17], Romania [3], and Ukraine [24].

In general, there are some common longtime trends in climate change for the countries of the Danube River Basin. These changes include increase in the average annual air temperature causing the decrease of snow percentage in the total annual amount of precipitation. This directly affects the river runoff by decreasing its rate in the spring season (shortage of snow and its more intensive melting) and increasing such rate in the autumn-winter period (rain-driven increase). In addition, there is a shift of peak values of snowmelt and rainwater runoff towards the beginning of the calendar year with the increased amplitude between the largest and lowest water discharges.

The analysis of the time series of observations over the runoff across the Danube Basin in Switzerland [21] based on application of statistical methods and Mann-Kendall nonparametric test showed statistically significant positive trends over the periods of 1931-2000, 1961-2000 and 1971-2000 (in the edition of the authors [21]). The increase of total annual runoff because of its growth over winter, spring and summer months was also observed. Gradual increase of air temperature leads to the decrease of the snowfall 
index and increase of runoff in winter season. At the same time, there is a shift of runoff peak values towards the beginning of a calendar year.

Starting from the second half of the 20th century, the average values of the Danube runoff at most water gauging stations in Germany show a positive trend. The maximum values of snowmelt and rainwater regime are characterized by a one-month shift, and the amplitude between the highest and lowest values of water runoff still continues its increase [20].

When analysing the influence of climate change on water resources in Austria over the period of 1951-2000 (data from 641 rainfall stations and 132 hydrological stations) the authors [22] completed a season Mann-Kendall test establishing statistical significance of such changes. The use of the Kendall-Theil test showed insignificant trends of annual precipitation and river runoff. However, some spatial and temporal differences could be observed after analysing the results over half-year and season periods. The trends in the change of precipitation regimes led to a more well-defined trend of river runoff increase over a cold period of the year (the north of the Alps) and a trend towards its decline over a warm period of the year (the south of the Alps, Carinthia and partly Styria).

The Hurst coefficient and spectrum analysis techniques enabled the authors of the research [23] to establish the statistical uniformity of multi-year daily, monthly and yearly river runoff regimes of the Danube River in Bratislava over the periods of 1876-1940 and 1941-2005. The research also confirmed the occurrence of multi-year cycles over the dry and wet periods. On the other hand, due to the increased air temperature for the last 65 years and an early snow melting process across the Danube River Basin an increase in the average multi-year daily water discharges in March and April is observed. At the same time a decrease of daily water discharge is observed in September. The long-term trend of a monthly water discharge over the observation period appeared to be close to zero, i.e. the influence of air temperature on the total annual runoff of the Danube River in Bratislava was indicated as insignificant.

The article [17] analysed the change of river runoff regimes across the Croatian part of the Danube River Basin for climate normals of a thirty-year period (1961-1990) and the next period of 1980-2009. A comparison of modular coefficients Parde 3 (the difference between the largest and the smallest Parde coefficient) made it possible to identify the changes between two time periods. The use of Kendall-Theil's nonparametric analysis for annual and seasonal river runoff time series indicated runoff decrease at almost all observation stations in the period of 1980-2009.

Application of a hydro-genetic method across the Ukrainian part of the Danube River Basin [24] made it possible to establish the fact that time series of spring floods from the beginning of observations to 2015 are homogeneous in their nature. As for their synchronous nature, it is characterized by four types of cyclic fluctuations which are different in duration and direction, and the mentioned fluctuations are caused by climatic and orographic peculiarities of the river basins under study.

The paper [25] presents a study of fluctuations and trends of time series of water levels and intra-annual distribution of river runoff at water gauging stations across the entire watercourse of the Danube River over the period of 1921-2010. The authors established that the trends of water level variation have a divergent nature along the entire length of the river. Thus, the time variation of maximum water levels has an unexpressed or a positive tendency. As for the average and minimum annual water levels, they are mainly associated with a negative trend.

However, downstream from the water gauging station (WGS) of Brăila (downstream from the Iron Gate-I hydropower plant) there are well-defined time trends of water levels increase over a multi-year period (1921-2010) [25]. On the other hand, the authors of the research [3] point out that the WGS located $220 \mathrm{~km}$ upstream from the Djerdap/Iron Gates dams show a shortage and decrease in the amplitude of multiyear and annual cycles of the Danube River water content.

The study of water resources change in different parts of the Danube River Basin resulting from the effects of future climate change was carried out by the authors of the article [14]. The Climate-Runoff water and heat balance 
model designed by Loboda [14] and the data of the REMO climatic model, A1B scenario [12, 19] made it possible to conclude that water resources changed in the south-eastern direction of the Danube River. In general, by 2030 the decrease of water resources in the Danube River will be minor constituting only $6.1 \%$.

The water resources of the Danube River mouth (in the territory of Ukraine) serve as a water supply source of human settlements. They play a major role in the development of irrigated agriculture and fishing industry across the arid southern part of Ukraine. With this objective in view there is an entire system of freshwater bodies such as lakes of Kagul, Kartal, Yalpug, Kugurlui, Safyan, Katlabukh and Kitay. The overall area of the lakes' water surface constitutes about 50 thousand hectares [1]. The lakes are connected with the Danube River through the channels equipped by special regulating facilities. During the periods of high water, the channels supply lakes with the water from the Danube River. During the periods of low water, the water is released back from the lakes in order to ensure the balanced mineralization of lakes.

The previous research [1] indicated the decrease of the current river runoff that supplies the lakes with water. The natural water exchange process is being disrupted. At the same time, the rate of water evaporation from the surface of the lakes keeps increasing. This reduces the water level and increases water salinity which determines the deterioration of water quality of the lakes. The water of low quality may not be used for the supply of drinking water and irrigation. Thus the Danube River runoff is the main component in the water-salt balance of lakes. Consequently, the study of trends of the river's hydrological regime across the Ukrainian part (downstream from the city of Reni) in a multiyear context has a great scientific and practical importance. The presented paper investigated the changes of the hydrological regime in the Danube River across the examined area, taking into account the anthropogenic impact and climate changes for the first time.

The aim of this article is to study the multiyear and current trends in changes of the hydrological regime of the Lower Danube across the Ukrainian territory from Reni to Izmail.
The analysis of hydrological regime covers the estimation of uniformity (homogeneity) and cyclic recurrence of water discharges (annual, maximum and minimum); trends testing of the time series taking into account anthropogenic factors and climate change; and calculation of the standard statistical parameters and their representation in the form of curves.

The results of this research may be used by hydrology engineers for the substantiation of the efficiency of regulation of the Danube Lakes filling pattern. On the other hand, the use of the mentioned lakes and the Danube River for water supply and irrigation purposes contributes to a successful social and economic development of the entire region.

\section{STUDY AREA}

The length of the Danube River is $2783 \mathrm{~km}$. The total area of its basin is 817 thous. $\mathrm{km}^{2}$. The Ukrainian part of the Danube River Delta is $170 \mathrm{~km}$ long (from the Prut River mouth to the Black Sea) and $54 \mathrm{~km}$ of it belongs to the river's main channel [25] (Fig. 1).

The Danube Delta is a low-land territory which is entirely located within the Lower Danube Plain and surrounded by Budzhak Plato from the north and by Dobrudzha Plato from the south [25]. The northern boundary of the delta stretches along the southern banks of Kugurlui, Katlabukh, Kytai and Sasyk lakes and reaches the sea coast. The state boundary between Ukraine and Romania stretches along the fairway across the near-delta zone of the Danube River and then along Kiliya branch and its mouths.

At the Izmailskyi Chatal Cape $(80 \mathrm{~km}$ from the mouth) the head of the delta is a place where the Danube's main channel is for the first time divided into two branches - Kiliya (Ukrainian) and Tulcea (Romanian). $17 \mathrm{~km}$ downstream the latter is divided into St. George and Sulina branches. The Sulina branch is a main international navigable waterway from the Danube to the Black Sea. The Kiliya branch (downstream from the city of Izmail), in its turn, is continually divided into numerous waterways or merges into a single waterway again. The Danube River flows into the Black Sea through its three main branches: Kiliya, St. George and Sulina. 


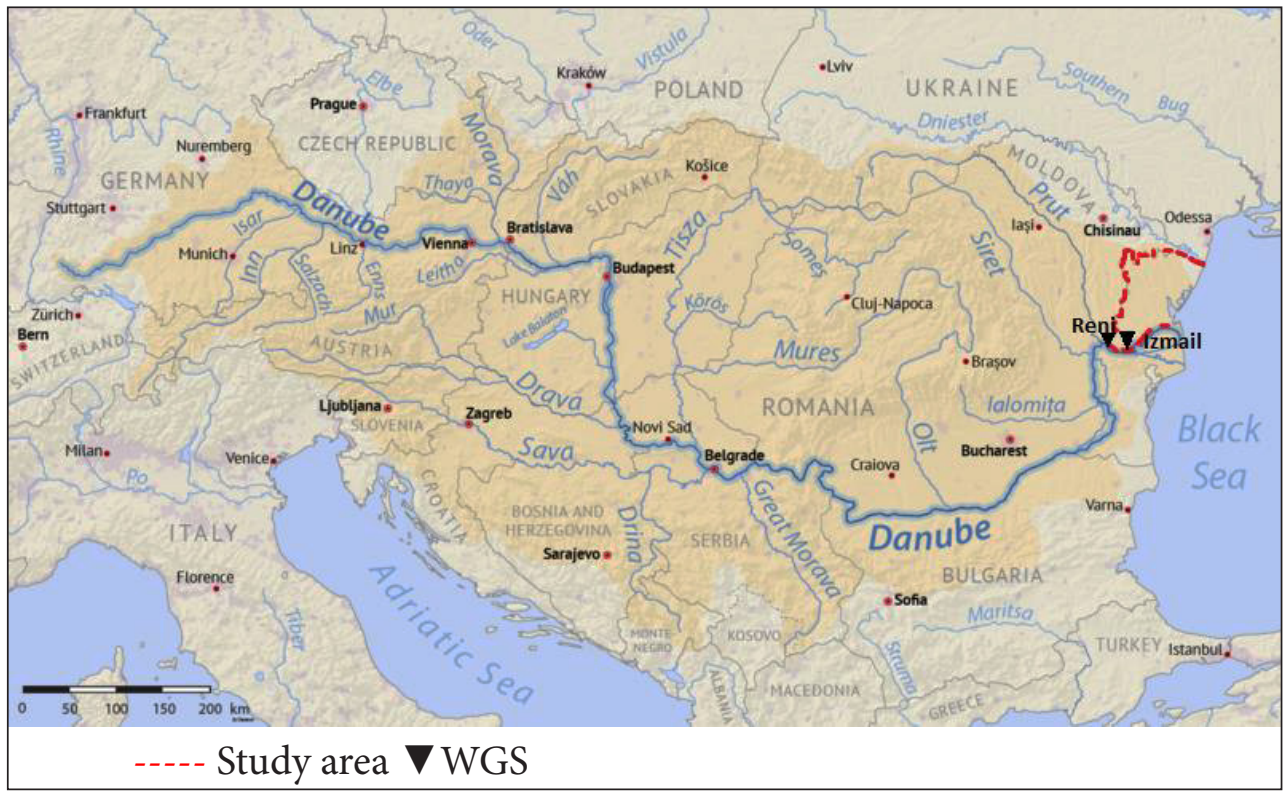

Fig. 1. Scheme of the Danube River Delta [https://en.wikipedia.org/wiki/Danube\#/media/File:Danube_basin.png]

The section of the Danube River from Reni to Izmail originates downstream of the Prut River mouth (city of Reni) and ends at the point which is slightly downstream from the place where the Danube is divided into Kiliya and Tulcea branches (city of Izmail) and has the overall length of $33.5 \mathrm{~km}$ (distance from town of Sulina (from the mouth) [25].

The runoff regime across the Lower Danube and at the Danube River Delta is characterized by the presence of well-defined long-lasting high floods which are formed by rainfalls or snowmelt and low river runoff during the summer-autumn period. The spring-summer high water consists of several waves of the flood which form at the Lower and Middle Danube and they are usually observed from March to July. This is the period of the annual maximum river runoff. The lowest water flow is observed during the summer-autumn period, i.e. from August to October. The level regime of the Danube River Delta is significantly affected by intra-annual water discharge variation, surges from near-mouth coastal waters, formation of ice events and construction of hydraulic engineering structures (diversion dikes, dams, etc.).

\section{DATA AND METHODOLOGY}

In order to identify changes of the characteristics of the Danube River runoff, the hydrological data (average annual, maximum and minimum water discharges) from the water gauging stations (WGS) of Reni ("54th Mile") and Izmail ("115th Kilometer") were chosen. Two periods of observations (1840-2015 for the analysis of the average annual river runoff and 1921-2015 for the analysis of maximum and minimum river runoff) were used, taking into account the reconstructed runoff (developed by the authors of [1]).

For the investigation of the anthropogenic influence on the river runoff in the study area, the authors of [1] divided the time series of average annual water discharges into the following three periods: the conventionally natural river runoff regime (1840-1920), the least altered river runoff regime (1921-1960) and the most altered river runoff regime (1961-2002).

The analysis of the future trends of river runoff formation is associated with the influence of global and regional climate changes on the Danube River basin [1,13]. The paper [16] considers 1989 to be a turning point in terms of the air temperature change in Ukraine and, accordingly, the rivers' hydrological regime change.

Therefore, the authors of the research selected the period of the most altered river runoff regime under the anthropogenic influence (1961-1989) and the period of modern water content which was observed during significant climatic changes (1990-2015). 
The statistical and mathematical methods were used to assess the characteristics of the longterm hydrological regime of the Lower Danube. The F-test (Fisher criterion) was used to assess the statistical homogeneity of the initial information [26]:

$$
F=\frac{\sigma_{x}^{2}}{\sigma_{y}^{2}},
$$

where $\sigma_{x}^{2}$ and $\sigma_{y}^{2}$ are dispersion of the studied data series.

A numerator should have a higher value of dispersion of two studied series. Fisher function depends on a number of degrees of freedom $k_{1}=n_{x}-1$ and $k_{2}=n_{y}-1$, where $n_{x}$ and $n_{y}^{2}$ stand for the duration of the studied series. The series may be considered homogeneous only if Fisher criterion is less than its critical value at the level of significance of $1 \%, 5 \%$, etc.

The assessment of cyclical fluctuations of river runoff was performed using the residual mass curves [26-29]. The current ordinates of residual mass curves from the time when a curve was plotted and by the end of $t^{\text {th }}$ year may be found using the following equation:

$$
\sum_{t=1}^{n}\left(k_{t}-1\right)=(t),
$$

where $k_{t}=Q_{t} / Q_{a v e}$ are modular coefficients of $t^{\text {th }}$ year; $Q_{t}$ and $Q_{a v e}$ are the discharge of $t^{\text {th }}$ year and the average discharge for the time period $n$.

Practical application of these methods may be seen in $[30,31,32]$.

Statistic parameters are calculated via the method of moments and the method of maximum likelihood [26]. According to the method of moments:

$$
\begin{aligned}
& Q_{\text {ave }}=\frac{1}{n} \sum_{t=1}^{n} Q_{t}, \\
& C_{v}=\sqrt{\frac{\sum_{t=1}^{n}\left(k_{t}-1\right)^{2}}{n-1},} \\
& C_{s}=\frac{n}{(n-2)(n-1)} \sum_{t=1}^{n}\left(k_{t}-1\right)^{3} / C_{v}^{3},
\end{aligned}
$$

where $Q_{\text {ave }}$ is an arithmetic mean value of dispensation feature $Q_{t}, C_{v}$ is the variation coefficient of dispensation feature $Q_{p}, C_{s}$ is the asymmetry coefficient of dispensation feature $Q_{p}$ and $n$ is the duration of observations (years).

When applying the method of maximum likelihood the auxiliary statistics $\lambda_{2}$ and $\lambda_{3}$ should be calculated first, with

$$
\lambda_{2}=\frac{1}{n} \sum_{t=1}^{n} \lg k_{t},
$$

and

$$
\lambda_{3}=\frac{1}{n} \sum_{t=1}^{n} k_{t} \lg k_{t} .
$$

Statistic parameters $C_{v}$ and relations $C_{s} / C_{v}$ are to be established using special nomograms specified in annexes of SNiP (Construction Norms and Regulations) 2.01.14-83 [26]. Their input values are presented by statistics $\lambda_{2}$ and $\lambda_{3}$.

\section{RESULTS AND DISCUSSION}

\section{Evaluation of the time series homogeneity of the Lower Danube runoff at different phases of water content}

The verification of homogeneity of time series of average annual water discharges was performed for the selected periods of water content of the Lower Danube. According to F-test (at the level of significance of $5 \%$ probability), the time series of observations at Reni and Izmail WGS should be considered uniform, i.e. the influence of anthropogenic factors (construction of the water reservoirs Iron Gate-I (1970) and Iron Gate-II (1984), damming etc.) and climatic changes did not have a major impact on the annual runoff in the Danube River Delta.

This conclusion is also confirmed by the research [33]. It is based on the analysis of the accumulation curve of the average annual water discharge of the Lower Danube (for the period of 1921-2010). The fact that observational data series may be considered having a homogeneous nature was established in the mentioned research. The plotted residual mass curves of the average annual runoff of some of the Danube's rivers are characterized by the presence of cycles of different duration. The analysis of the combined graphs indicated the synchronism of annual water discharge fluctuations at different WGSs across the studied region [30,33]. 
The lack of uniformity of time series of maximum and minimum water discharges may be observed over the period when hydraulic engineering structures started to affect the river's hydrological regime (in 1961 [1]) and, later, when hydropower plants of Iron Gate-I (1970) and Iron Gate-II (1984) were constructed across the Lower Danube as well as the hydraulic engineering works took place across the branches of the Danube Delta (Sulina in 1968-1982 and St. George in 1981-1992). At the same time, the influence of climatic changes on the river runoff in the early 1990s was less significant during formation of maximum and minimum discharges of both WGSs. The time series of river runoff over the period of 1990-2015, as compared with the preceding period of 1961-1989, remained homogeneous.

\section{Research of the time regime of the Lower} Danube River runoff at the Reni-Izmail area Average annual water discharges. An analysis of the reconstructed multi-year series (1840-2015, i.e. over the period of 176 years) of average annual water discharges of the Danube River across its length from Reni to Izmail (in the form of modular coefficients $k_{t}$ of $t^{\text {th }}$ year) is presented in this research.
The analysis indicated the presence of a weakly expressed, almost two centuries long trend towards its increase (Fig. 2) and its cyclic recurrence in the course of time over different periods of water content in the Lower Danube (Fig. 3).

The study of residual mass curves of the aggregate multi-year series (1840-2015) of average annual water discharges of the Danube River across its length from Reni to Izmail (Fig. 3) characterizes the period of the conventionally natural regime of river runoff and the low-water one in 1840-1910. The period of the least altered regime of river runoff (up to 1960) was characterized by a neutral trend with annual water discharge fluctuations of short duration. Over the period of the most altered runoff regime from the 60 s to 80 s of the last century a positive trend was established. The extension of time series of average annual water discharges up to 2015 showed, alternatively to the authors' conclusion [1], that over the period after 1989 (the period of significant climatic changes) there was a trend towards a certain decrease of the mentioned annual water discharges across the lower course of the Danube River. The decrease was then followed by a slow increase. Such findings were also confirmed by the research [33]. According to

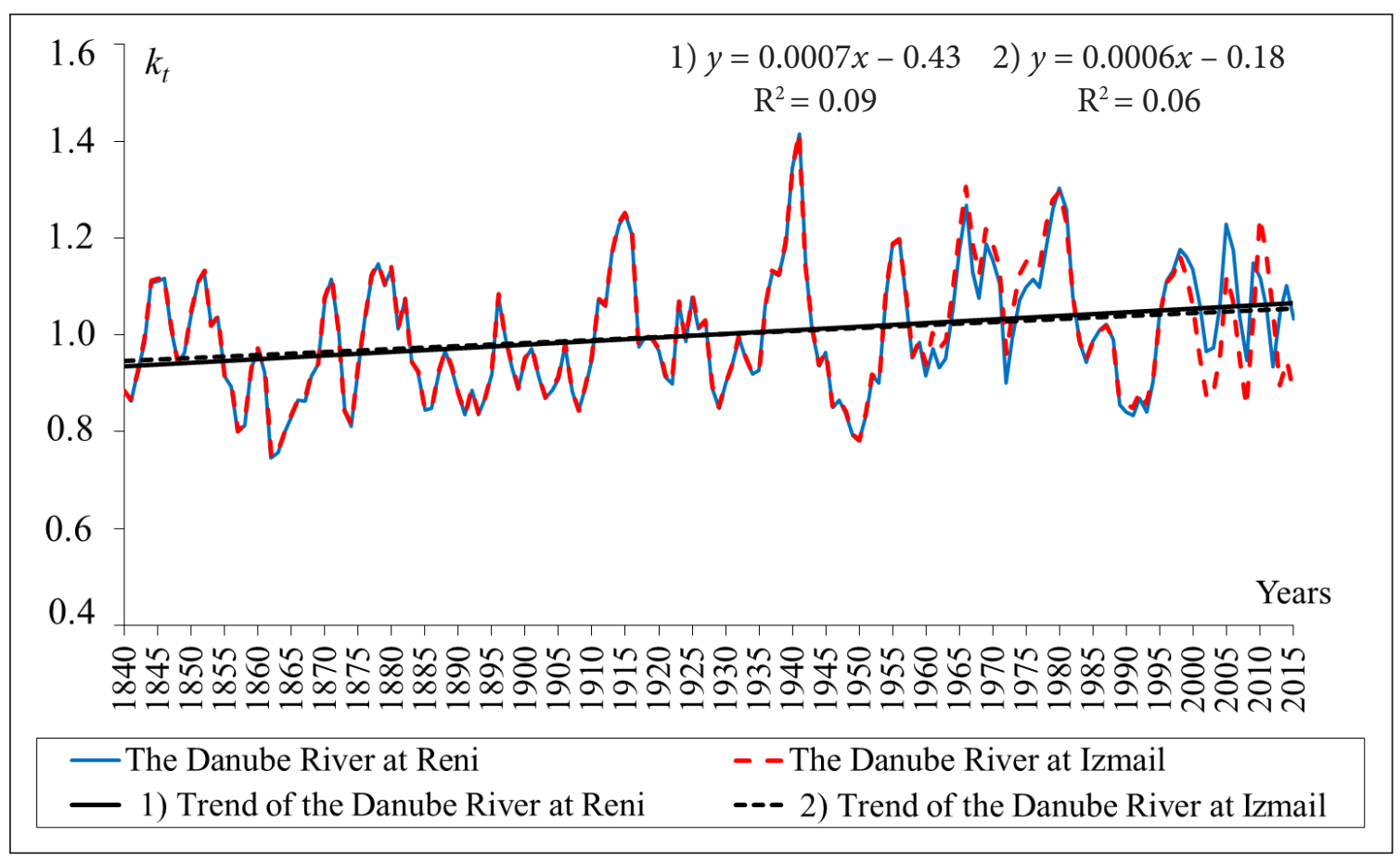

Fig. 2. Time series of the modular coefficient of average annual water discharges (three-year moving averages) and their trends in the Danube River across its length from Reni to Izmail 


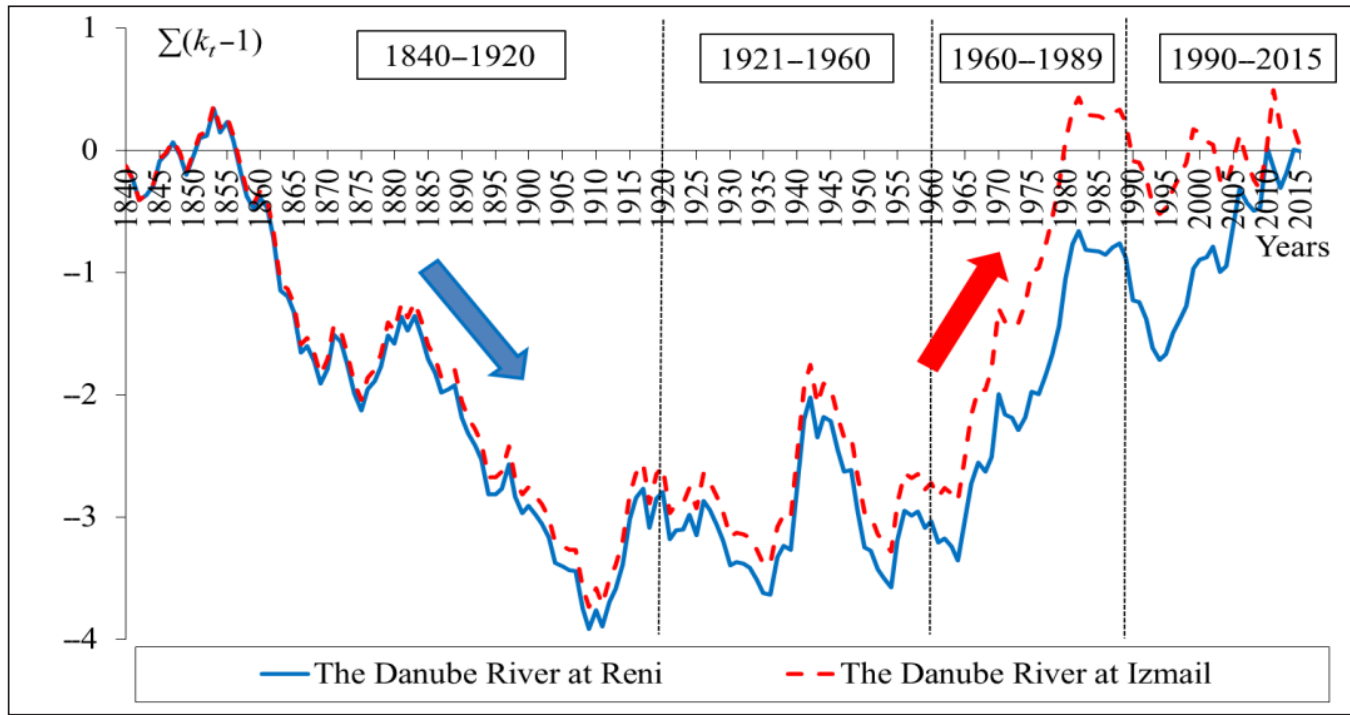

Fig. 3. Residual mass curves of the modular coefficient of average annual discharges of the Danube River across its length from Reni to Izmail

its authors, the commencement of a high-water stage of water content across the lower course of the Danube River started in 1995.

The overall increase of the Danube River runoff resulting, in addition to climatic factors, from anthropogenic factors, such as river channel reg- ulation across the near-delta area, was established (1987-1991) [1, 10].

Maximum water discharges. Multi-year variation of maximum water discharges over the period of 1921-2015 (Fig. 4) showed a slight increase of maximum annual water discharges over the last

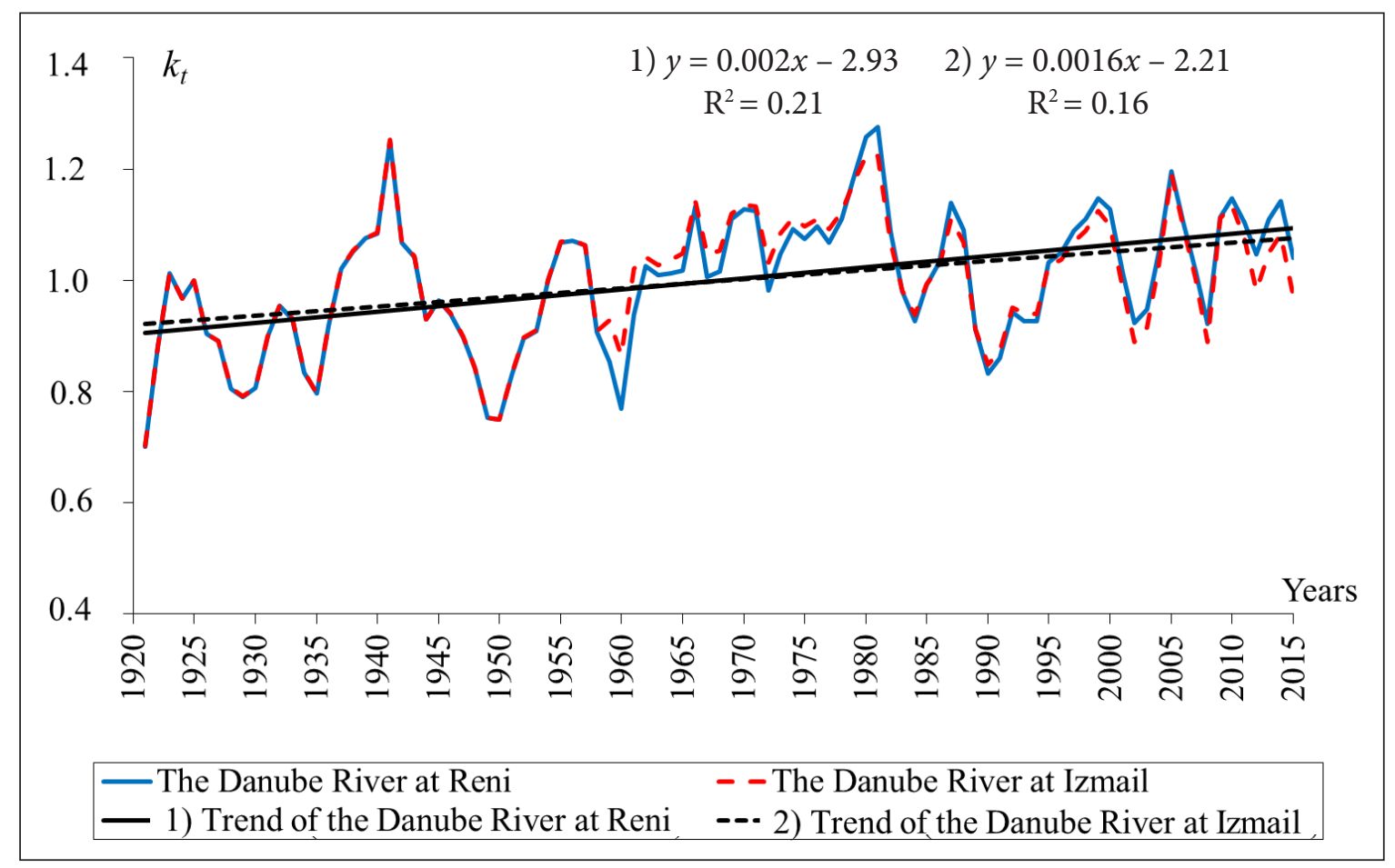

Fig. 4. Time series of the modular coefficient of the maximum water discharges (three-year moving averages) and their trends in the Danube River across its length from Reni to Izmail 
years. Such increase, in its turn, led to the water content increase in the Danube River (Fig. 2).

The analysis of residual mass curves of maximum water discharges over the period of 19212015 (Fig. 5) showed that the multi-year period of maximum discharges consisted of two periods. The first one is actually characterized by the presence of a negative trend (1921-1960) and the second one by a positive trend (1961-2015). It is worth noting that over the period from 1989, a less intensive growth of maximum water discharges was estimated due to climatic changes and changes of the rivers' water regime during this period, especially because of rainfalls or snowmelt occurring within the basin.

Minimum water discharges. The study of time series of minimum water discharges progress (three-year moving averages) of the Danube River across its length from Reni to Izmail showed minor positive trends (Fig. 6). The authors of [1]

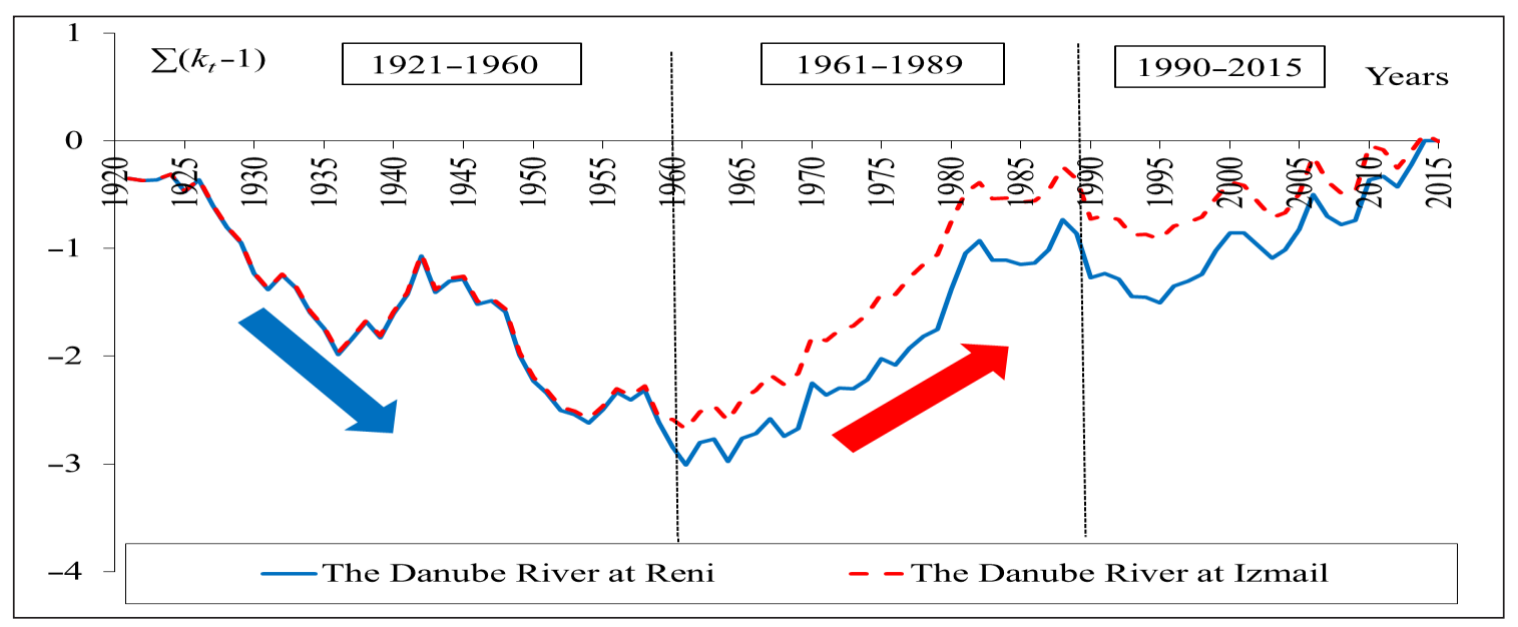

Fig. 5. Residual mass curves of the modular coefficient of the maximum water discharges of the Danube River across its length from Reni to Izmail

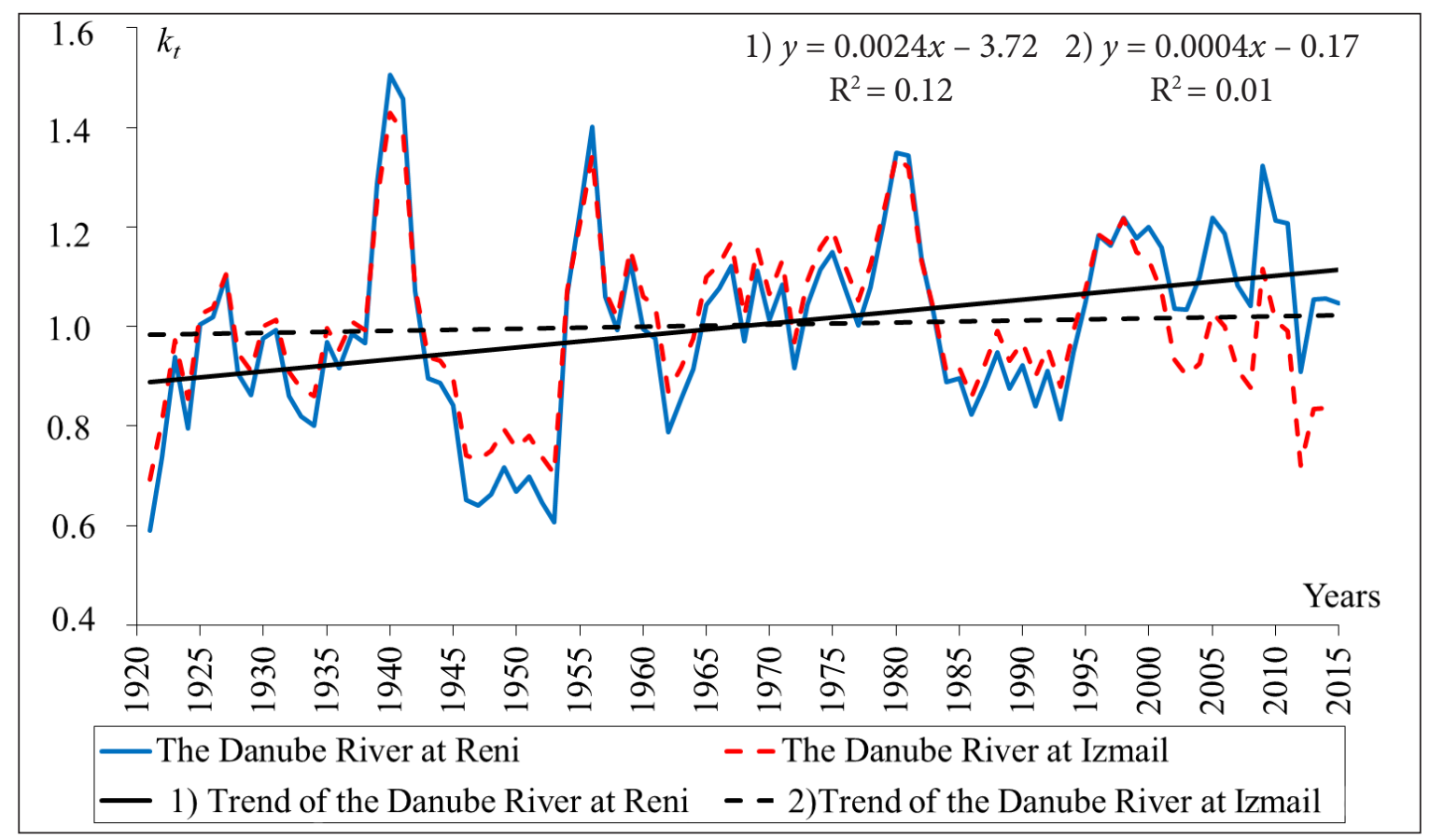

Fig. 6. Time series of the modular coefficient of minimum water discharges (three-year moving averages) and their trends in the Danube River across its length from Reni to Izmail (1921-2015) 
explain such increase of minimum water discharges as a result of possible water discharge to the tailrace of installations of Iron Gate-I and Iron Gate-II water reservoirs during summer-autumn low-water period. At the same time the authors [1] believe that the average value of minimum water discharges remained almost the same.

The analysis of residual mass curves of minimum water discharges of the Danube River across its length from Reni to Izmail (1921-2015) showed their synchronism during low-water period for both of the WGS (Fig. 7). However, over the period since the 2000s a mismatch of trends of low-water discharge across the Danube Delta at WGS Reni ("54th Mile") and WGS Izmail ("115th Kilometer") could be observed. This might be caused by the redistribution of river runoff between the branches of the delta - a decrease in the runoff volume of Kiliya branch and an increase of the same Tulcea branch - mainly due to water content increase of Sulina branch. In addition, the construction of the hydrotechnical structures aimed at artificial shortening of St. George branch (1981-1992) led to the redistribution of water content in the Danube Delta. Accordingly, the construction of the "35th Mile" channel in 1983 draws away a significant volume of Tulcea branch runoff. These engineering activities caused the increase of the average annual river runoff in St. George branch [1].

\section{Statistical characteristics of the studied time series}

The statistical processing of the aggregate multi-year series of water discharges using the methods of moments and the maximum likelihood method made it possible to obtain the standard distribution parameters such as average values $\left(Q_{\text {ave }}, \mathrm{m}^{3} / \mathrm{s}\right)$, variation coefficients $\left(\mathrm{C}_{v}\right)$ and asymmetry coefficients $\left(\mathrm{C}_{s}\right)$ or their ratio $\left(\mathrm{C}_{\sqrt{ }} / \mathrm{C}_{s}\right)$. The statistical parameters of time series of average, maximum and minimum annual water discharges in WGS Reni ("54th Mile") and in WGS Izmail ("115th Kilometer") are presented in Table 1.

For the period of the series of average annual water discharges (1840-2015) the variation coefficients for both WGS are equal to 0.19 each and the ratio $\mathrm{C}_{\nu} / \mathrm{C}_{s}$ equal to 2.1-2.4. For the maximum water discharges of hydraulic sections in Reni and Izmail (for the period of 1921-2015) the obtained variation coefficients are equal to 0.18 and 0.17 , respectively. The $\mathrm{C}_{v}$ of the minimum water

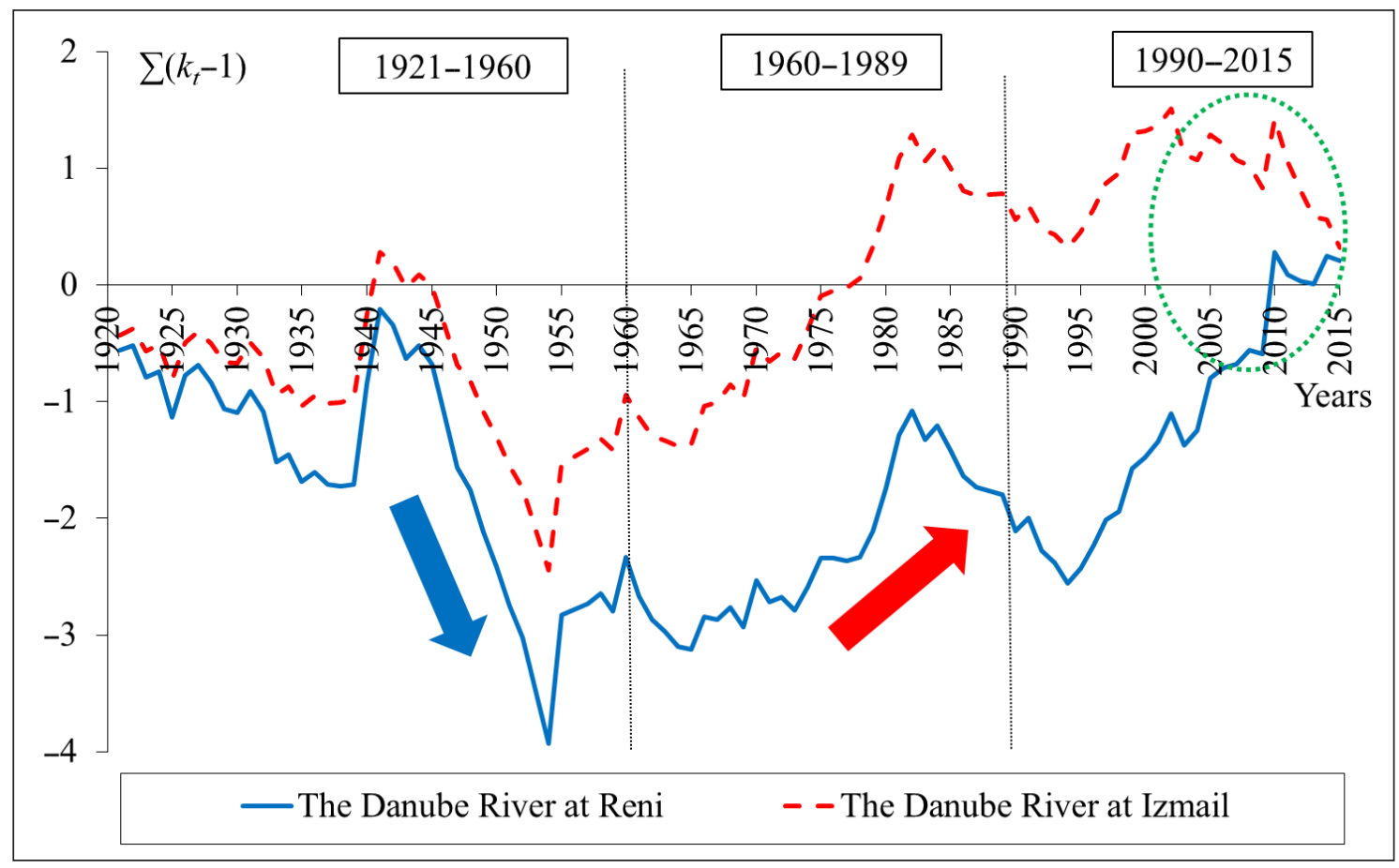

Fig. 7. Residual mass curves of the modular coefficient of the minimum water discharges of the Danube River across its length from Reni to Izmail (1921-2015) 
Table 1. Statistical characteristics of time series of the Danube River runoff at Reni and Izmail

\begin{tabular}{|c|c|c|c|c|c|c|c|c|}
\hline \multirow{2}{*}{ Statistical value } & \multirow{2}{*}{$Q_{a v e}, \mathrm{~m}^{3} / \mathrm{s}$} & \multirow{2}{*}{$r(1)$} & \multicolumn{3}{|c|}{ Method of moments } & \multicolumn{3}{|c|}{ Maximum likelihood method } \\
\hline & & & $C_{v}$ & $C_{s}$ & $C_{s} / C_{v}$ & $C_{v}$ & $C_{s}$ & $C_{s} / C_{v}$ \\
\hline \multicolumn{9}{|c|}{ Danube River - Reni } \\
\hline Average & 6355 & 0.25 & 0.19 & 0.44 & 2.40 & 0.19 & 0.45 & 2.40 \\
\hline Maximum & 11266 & 0.18 & 0.18 & 0.03 & 0.20 & 0.18 & 0.08 & 0.40 \\
\hline Minimum & 2926 & 0.11 & 0.29 & 1.05 & 3.60 & 0.29 & 1.09 & 3.70 \\
\hline \multicolumn{9}{|c|}{ Danube River - Izmail } \\
\hline Average & 3695 & 0.27 & 0.19 & 0.40 & 2.10 & 0.19 & 0.42 & 2.20 \\
\hline Maximum & 6242 & 0.16 & 0.17 & -0.03 & -0.20 & 0.17 & 0.02 & 0.10 \\
\hline Minimum & 1810 & 0.09 & 0.25 & 1.03 & 4.20 & 0.24 & 1.09 & 4.50 \\
\hline
\end{tabular}

discharges is slightly higher at the section in Reni and constitutes 0.29 . The ratio $C / C_{v}$ of maximum water discharges during the spring-summer high water periods constituted $0.20-0.40$ in Reni, whereas a slight reduction by -0.2 and 0.1 was obtained in Izmail. The $C / C_{v}$ of minimum water discharges is significantly higher, initially constituting 3.60-3.70 at the section of Reni and increasing to $4.20-4.50$ at Izmail.

The analysis of the statistical characteristics of the whole hydrological year may be complemented by the study of the intra-annual distribu- tion of such characteristics over different phases of water content. The intra-annual change of average monthly water discharge variation coefficients for the Danube River in Reni and Izmail (1960-2015) is shown in Fig. 8.

It is seen that the coefficients of monthly water discharge variation obtained using the method of moments and the maximum likelihood method are almost the same. They change from their smallest values of $0.24-0.28$ (in FebruaryMay) to the largest ones of $0.34-0.37$ (in JulyAugust and in November) (Fig. 8). The average

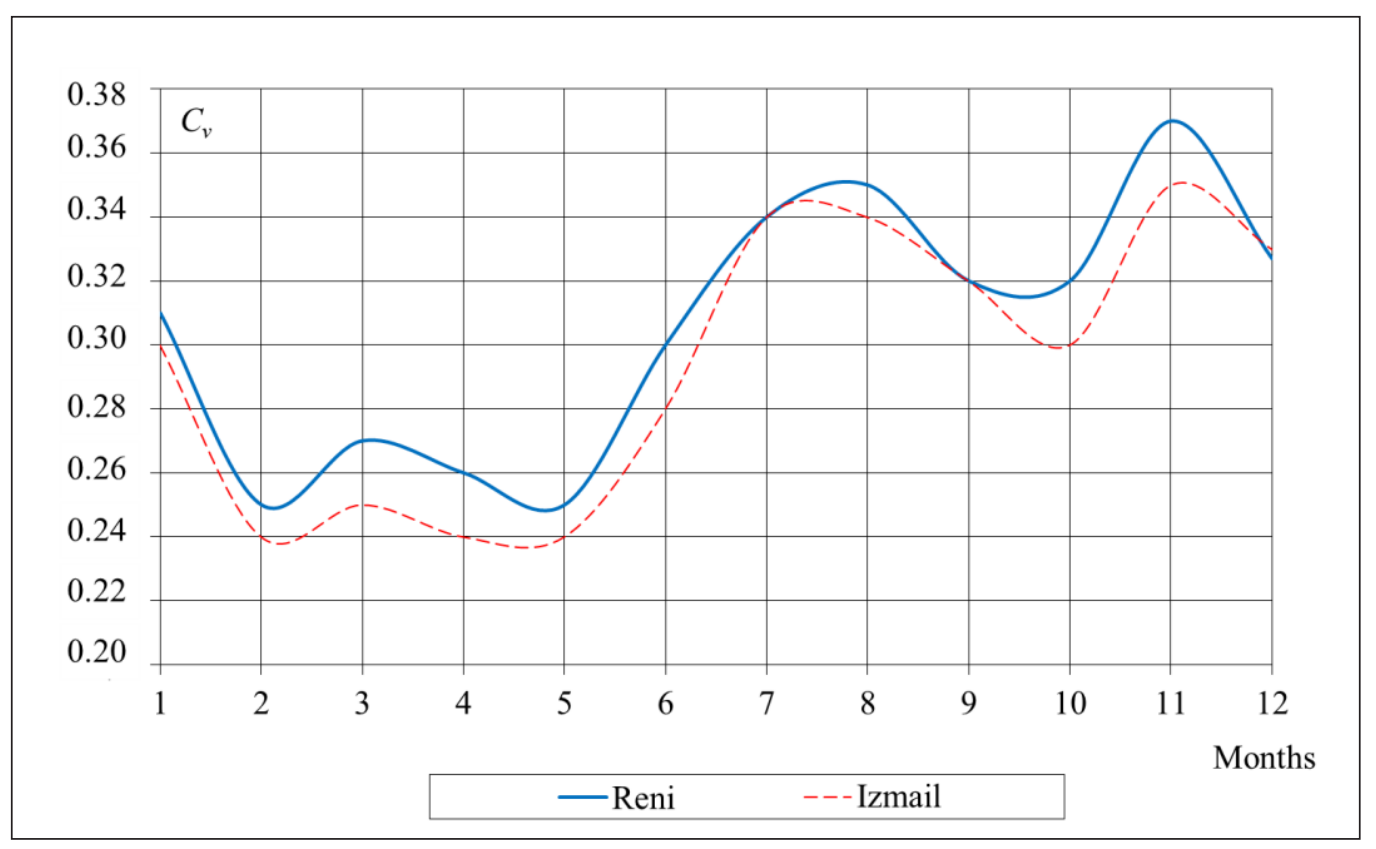

Fig. 8. Intra-annual change of variation coefficients of the average monthly water discharge in the Danube River at Reni and Izmail (1960-2015) 
monthly ratios $C_{s} / C_{v}$ constitute 1.85 for Reni and 1.53 for Izmail.

As for average monthly water discharges of the Danube River at Reni and Izmail the same type of intra-annual distribution runoff depending on the water content of a certain season may be observed (Fig. 9). The runoff regime of the Lower Danube is characterized by a rather high and long spring-summer overflow period due to rainfall or snowmelt and by a summer-autumn low water period. The most high-water months include April, May and June, the most low-water ones are September, October and November.

\section{CONCLUSIONS}

The research of the Danube River hydrological regime (in the territory of Ukraine) showed its great practical importance in the light of large demand for water and social and economic development of the entire region. The Danube River runoff is vital for water supply and irrigation and ensures

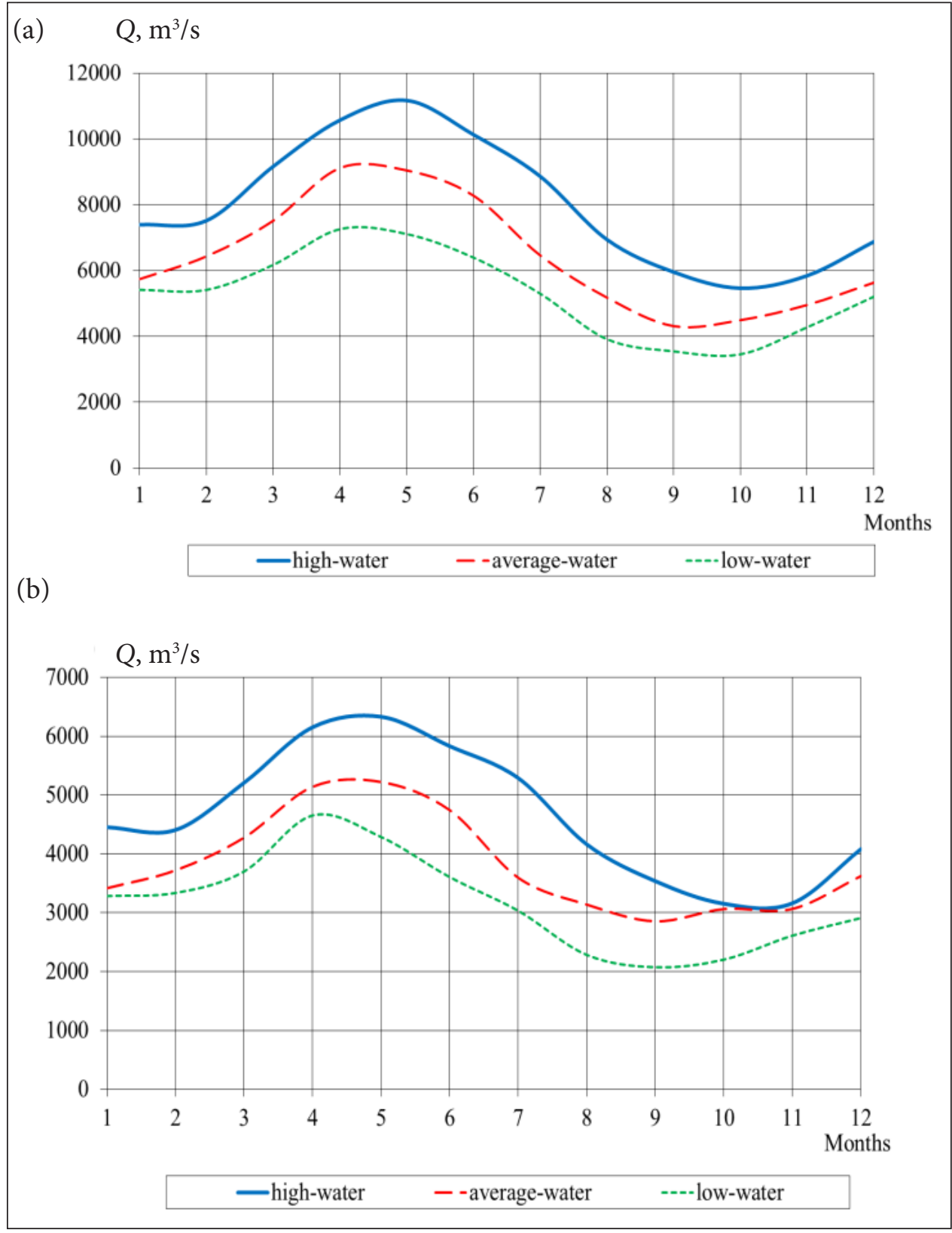

Fig. 9. Intra-annual distribution of water discharge in the Danube River at Reni (a) and Izmail (b) (1960-2015) 
a more efficient management of the filling of Danube Lakes with fresh water and maintenance of their water-salt balance.

The analysis of the current state of the hydrological regime in the Lower Danube shows that natural and anthropogenic changes which affect the water discharge should be considered separately.

Anthropogenic factors are mainly related to hydraulic engineering structures which have been actively implemented since the 1960s and led to the regulation of the Danube River runoff. Such structures caused a redistribution of the long-term runoff of the Danube River across its delta (Kiliya and Tulcea branches) with the increase of water content in the Romanian part of the delta (Tulcea branch) and its decrease in the Ukrainian part (Kiliya branch).

The impact of climate change on the water regime of the rivers of the Danube Countries (especially in the territory of Ukraine) has been manifesting itself over the last thirty years of the retrospective period.

Thus, verification of the homogeneity of time series of average annual, maximum and minimum water discharges was performed for different periods of water content of the Lower Danube. Such periods include the natural regime of river runoff (1840-1920), the least altered river runoff regime (1921-1960) and the most altered river runoff regime under the anthropogenic influence (1961-1989). The determination of climate change impact on the Lower Danube River allowed introduction of a new, present period of its hydrological regime (1990-2015).

According to F-test (at the significance level of 5\%) time series of average annual water discharges at Reni and Izmail WGSs should be considered uniform, i.e. the influence of anthropogenic factors and climatic change did not have a major impact on the annual river runoff of the Danube Delta as a whole. However, if we consider the different phases of water content separately, there are still some changes. For instance, the lack of uniformity of the time series of the maximum and minimum discharges may be observed over the period when hydraulic engineering structures started to affect the river's hydrological regime (in 1961). At the same time, the influence of climatic changes on the river runoff in the late 1980s did not have any influence on the time series of such water discharges.

Although the annual runoff series proved to be homogeneous in time, the analysis of the aggregate multi-year series (1840-2015, i.e. over the period of 176 years) of the Danube River average annual water discharges across its length from Reni to Izmail indicated the presence of a weakly expressed, almost two centuries long trend towards their increase.

The authors also performed the analysis of the cyclicity and uniformity of the annual water discharges in the course of time over different periods of the Lower Danube water content. The period of conventionally natural river runoff regime (1840-1910) may be considered having a negative trend, whereas the period of the least altered runoff regime (up to the 1960s) has a neutral trend. Over the period from the $60 \mathrm{~s}$ to $80 \mathrm{~s}$ of the last century (i.e. over the period of the most altered runoff regime and before the significant impact of climatic changes) a positive trend was observed. The period after 1989 (the period of significant climatic changes) had a trend towards a certain decrease of the annual river runoff up to 1994 and a slow increase (starting from 1995) of the annual river runoff across the lower course of the Danube River.

The study of long-term variations of maximum water discharges over the period of 19212015 showed that the maximum water discharges featured a slight increase. It should be also noted that the time series of observations are characterized by the period with a negative trend (1921-1960) and the period with a positive trend (1961-2015) of the maximum water discharge. In addition, the period of climatic changes (after 1989) is also characterized by a less intensive growth of maximum water discharges.

The construction of chronological charts of the minimum water discharges across the Danube River from Reni to Izmail allowed the identification of insignificant positive trends and synchronicity of their course over the interim period for both of the WGSs. However, since the 2000s such synchronous trend was disrupted due to the redistribution of water discharge between the Danube Delta branches.

It was also established that the intra-annual course of average monthly water discharges of the Danube River at Reni and Izmail river sections 
during the high-water, middle-water and low-water years (for the combined series of data from 1960 to 2015) was characterized by the homogeneity of river runoff depending on the water content of a certain season.

Thus, the positive trends and water-rich cycles characteristic of the Ukrainian part of the Danube River in multi-year series of average, maximum and even minimum water discharges (at Reni) will contribute to the efficient regulation of the Danube Lakes filling process. Minor changes of water resources of the Danube River caused by climate change effects will also create the favourable conditions allowing water supply and irrigation in the region.

Received 1 June 2019 Accepted 2 September 2019

\section{References}

1. Mikhailov V. N. (ed.). Hydrology of the Danube Delta. Moscow: GEOS edition, 2004. 448 p.

2. Best J. Anthropogenic stresses on the world's big rivers. Nature Geoscience. 2019. No. 12. P. 7-21.

3. Stratimirovic D., Batas-Bjelic I., Djurdjevic V., Blesic S. Changes in long-term properties of the Danube river level and flow induced by damming. Water Resources Research. 2019. P. 1-25.

4. Gross M. A global megadam mania. Current Biology. 2016. No. 26. P. 779-782.

5. Zarf C., Lumsdon A. E., Berlekamp J., Tydecks L., Tockner K. A global boom in hydropower dam construction. Aquatic Sceinces. 2015. No. 77. P. 161-171.

6. Almazov A. M., Bondar K., Vagin N. F., et al. Hydrology of the Danube Delta Mouth Region. Ed. by Nikiforov Ya. D. and Dyakonu K. Moscow: Gidrometizdat, 1963. 384 p. (in Russian).

7. Strategy for the Danube Region: A History of Success. 2016 (in Bulgarian). http://ec.europa.eu/ regional_policy/sources/cooperate/danube/documents/eusdr_success_stories_bg.pdf

8. Oen D., Theologitis D., Urrutia B. Inland navigation developments in the EU 2016. Eighty-Seventh Session of the Danube Commission, Budapest, 14 Dec. 2016.
9. Pencheva V., Asenov A., Sładkowski A., Georgiev I., Beloev I., Ivanov K. The Danube River. In: Sładkowski A. (ed.). Modelling of the Interaction of the Different Vehicles and Various Transport Modes. Silesian University of Technology Katowice, Poland: Lecture Notes in Intelligent Transportation and Infrastructure, Springer. 2018. P. 233-288.

10. Kornilov M. V. Long-term redistribution of water runoff along the branches of the Danube Delta. Proceedings of the 5th Conference "Dynamics and Thermal of Rivers, Reservoirs and Adjacent Seas", Moscow, Institute of Water Problems. 1999. P. 424425 (in Russian).

11. Cheroy O. I. The redistribution of runoff on the branches of the Danube Delta in terms of the existence of navigation channels. Ukrainian Hydrometeorological Journal. 2013. No. 13. P. 176-182 (in Ukrainian).

12. Stagl J. C., Hattermann F. F. Impacts of climate change on the hydrological regime of the Danube River and its tributaries using an ensemble of climate scenarios. Water. 2015. No. 7. P. 6139-6172.

13. Bisselink B., Bernhard J., Gelati E., Adamovic M., Jacobs C., Mentaschi L., Lavalle C. and De Roo A. Impact of a changing climate, land use, and water usage on water resources in the Danube river basin. JRC Technical Reports, European Commission, 2018. $70 \mathrm{p}$.

14. Loboda N. S., Bozhok Yu. V. Assessment of water resources change of the Danube River in the XXI century under the scenario A1B using the model “Climate-Runoff”.Ukrainian Hydrometeorological Journal. 2016. No. 18. P. 112-120 (in Ukrainian).

15. Gopchenko Ye. D., Ovcharuk V. A., Shakirzanova $\mathrm{Zh}$. R. The influence of modern climate changes on the characteristics of maximum runoff of spring flood on the rivers of Polissia. Hydrology, Hydrochemistry and Hydroecology. 2010. Vol. 3. No. 20. P. 50-59 (in Ukrainian).

16. Grebin V. V. Modern Water Regime of the Rivers of Ukraine (Landscape and Hydrological Analysis). Kyiv: Nika-Tsentr, 2010. 316 p. (in Ukrainian).

17. Čanjevac I. Novije promjene protočnih režima u hrvatskom dijelu poriječja Dunava. Hrvatski Geografski Glasnik. 2012. Vol. 74. No. 1. P. 61-74.

18. Blöschl G. et al. Changing climate shifts timing of European foods. Science. 2017. No. 357. P. 588-590. 
19. Storch H., Bray D. Models, manifestation and attribution of climate change. Meteorology Hydrology and Water Management. 2017. Vol. 5. No. 1. P. 47-52.

20. Bormann H. Runoff regime changes in German rivers due to climate change. Erdkunde. 2010. Vol. 64. No. 3. P. 257-279.

21. Birsan M.-V., Molnar P., Burlando P., Pfaundler M. Streamflow trends in Switzerland. Journal of Hydrology. 2005. No. 314. P. 312-329.

22. Fürst J., Kling H., Nachtnebel H. P., Hörhan T. Trends in hydrologischen Variablen und in der Wasserbilanz Österreichs. In: Nachtnebel H. P. (Hrsg). Auswirkungen des Klimawandels auf die Österreichische Wasserwirtschaft. Bundesministerium für Land- und Forstwirtschaft, Umwelt und Wasserwirtschaft, Beč, Austria. 2008. P. 105-115.

23. Pekárová P., Miklánek P., Onderka M., Halmová D., Mitková V. B., Mészároš I., Škoda P. Flood regime of rivers in the Danube River basin. Regional cooperation of Danube Countries within the framework of UNESCO International Hydrological Program, PROJECT 9, 2008. 51 p.

24. Zabolotnia T., Gorbachova L., Khrystiuk B. Estimation of the long-term cyclical fluctuations of snow-rain floods in the Danube basin within Ukraine. Meteorology Hydrology and Water Management. 2019. Vol. 7. No. 2. P. 1-9.

25. Hydrologisches Nachschlagewerk der Donau 19212010. Donau Kommission, Budapest. 2018. 328 p. http://www.danubecommission.org/uploads/ doc/publication/2018/spravocnik_1921_2010.pdf
26. Manual to Determining the Calculated Hydrological Characteristics. Leningrad: Gidrometeoizdat. 1984. 447 p. (in Russian).

27. Rippl W. The capacity of storage reservoirs for water supply. Proceedings of the Institute of Civil Engineers. 1883. Vol. 71. P. 270-278.

28. Sudler C. Storage required for the regulation of streamflow. Transactions of the American Society of Civil Engineers. 1927. Vol. 91. P. 622-660.

29. Guide to Hydrological Practices. Data Acquisition and Processing, Analysis, Forecasting and Other Applications. 5th edition. WMO. 1994. No. 168. 735 p.

30. Gorbachova L., Bauzha T. Complex analysis of stationarity and homogeneity of flash flood maximum discharges in the Rika River basin. Energetika. 2013. Vol. 59. No. 3. P. 167-174.

31. Rachmatullina E., Grebin V. Homogeneity analysis of winter regime characteristics for the Southern Bug river basin. Energetika. 2014. Vol. 60. No. 3. P. 184-196.

32. Gorbachova L. The intra-annual streamflow distribution of Ukrainian rivers in different phases of long-term cyclical fluctuations. Energetika. 2015. Vol. 61. No. 2. P. 71-80.

33. Gorbachova L., Khrystyuk B. Hydro-genetic methods of the analysis of the average annual runoff in the Danube basin. In: Dorner W., Marquardt A., Schroder U. (eds.). Proceedings of the Danube Conference: Bridging the Sciences - Crossing Borders. 22-24 September 2014, Deggendorf, Germany. P. 71-74. 
Yelyzaveta Romanova, Zhannetta Shakirzanova, Valeria Ovcharuk, Olena Todorova,

Iuliia Medvedieva, Andrii Ivanchenko

DAUGIAMETE் VANDENS DEBITŲ KAITA DUNOJAUS UPĖS ŽEMUPYJE TARP RENIO IR IZMAJILO ATSIŽVELGIANT İ GAMTINIŲ IR ANTROPOGENINIŲ VEIKSNIŲ ITTAKĄ

\section{Santrauka}

Dunojaus upès žiotys yra pagrindinis gèlo vandens šaltinis sausringoje pietinèje Ukrainos dalyje. Vanduo naudojamas drèkinimui, juo papildomi Dunojaus deltos ežerai. Klimato pokyčiai ir daugybè socialinių bei ekonominių veiksnių mažina Dunojaus ežerų plotą ir vandens lygí, didina jų druskingumą. Tokiomis aplinkybėmis vandens mainai tarp Dunojaus upès ir jos ežerų yra labai svarbus procesas, leidžiantis išlaikyti pastarųjų vandens ir druskos pusiausvyrą. Tokie vandens mainai labai priklauso nuo Dunojaus upès nuotèkio režimo.

Straipsnyje pateikiami Dunojaus upès žemupyje būdingų vandens debitų pokyčiai, susiję su natūralių ir antropogeninių veiksnių, turinčių ịtakos upių nuotèkio svyravimams, įvertinimu. Tyrimui naudotų Renio ir Izmajilo vandens matavimo stočių vidutinio metinio vandens debito duomenų eilutès buvo laikomos vienodomis pasirinktais laikotarpiais. Laikotarpiai buvo suskirstyti ị natūralaus upès nuotèkio (1840-1920), mažiausiai pakitusio upès nuotėkio (1921-1960) ir labiausiai pakitusio upès nuotèkio, esant stipriam antropogeniniam poveikiui (19611989). Klimato pokyčių ịtakos upių nuotèkiui analizè leido ịvesti naują Dunojaus upès hidrologinio režimo periodą (1990-2015). Nustatyta, kad maksimalių ir minimalių vandens dabitų duomenų eilutèms būdingas jų nevienodumas esant hidrotechninių statinių ittakai (nuo 1961 m.) lyginant su natūralaus hidrologinio režimo laikotarpiu. Išanalizavus daugiametę Dunojaus upès metinių, maksimalių ir minimalių debitų kaitą 1840-2015 m. ties Reniu ir Izmajilu buvo nustatytos teigiamos šių rodikliu kaitos tendencijos. Tuo pat metu, didžiausių klimato pokyčių laikotarpiu (po 1989 m.), būdingas ne toks intensyvus maksimalaus debito kilimas. Tyrimais buvo nustatytas vandens debitų svyravimų cikliškumas ir sinchroniškumas Dunojaus upès žemupyje ties Renio ir Izmajilo vandens matavimo stotimis Ukrainos teritorijoje. Tyrimas pirmą kartą parodè, kad nuo 2000 m. upių nuotėkio persiskirstymas tarp Dunojaus upès atšaku lèmè minimalaus upių nuotèkio nesinchroniškumą skirtingose Dunojaus deltos dalyse. Šio tyrimo rezultatai atskleidè, kad norint veiksmingai reguliuoti Dunojaus ežerų papildymą inžinerinèmis priemonèmis, būtina išsami Dunojaus upès hidrologinio režimo pokyčių analizė besikeičiančio klimato sąlygomis. Toks reguliavimas užtikrintų vandens tiekimą ir drèkinimą analizuotame regione.

Raktažodžiai: Dunojaus upè, upių nuotėkio hidrologinis režimas, trendų analizè, antropogeniniai veiksniai, klimato kaita 